\title{
A Case of Excessive Masturbation Treated with Aripiprazole
}

\author{
Muslum Kul' ${ }^{1}$, Hayriye Baykan², Hasan Kandemir ${ }^{3}$
}

ÖZET:

Aripiprazol ile tedavi edilen aşırı masturbasyon olgusu

Çocukluk çağı masturbasyonu; çocuğun genital bölgelerini ritmik şekilde uyarması ve buna eşlik eden terleme, flushing ve taşipne ile karakterizedir. Tedavisinde genellikle ilaç kullanılmasına gerek duyulmaz. Ancak mastürbasyonun sıklığı çok fazla ise ve ev ortamı dışında yapılıyorsa, ilaç tedavisi gerekebilmektedir. Bu yazıda aşırı masturbasyon nedeniyle okula devam edemeyen ve aripiprazolle tedavi edilen bir olgu sunulmuştur.

Anahtar sözcükler: çocukluk çağı masturbasyonu, aripiprazol

Klinik Psikofarmakoloji Bulteni 2014;24(1):93-6
ABSTRACT:

A case of excessive masturbation treated with aripiprazole

Childhood masturbation is defined as self-stimulation of the genitalia by a prepubertal child, frequently accompanied by symptoms like sweating, flushing and tachypnoea. Generally, no drug therapy is required in childhood masturbation. If the frequency of masturbation is too high and it is performed near strangers and out of the home environment, drug treatment may be necessary. A case of excessive masturbation that seriously disturbed the functionality of the child, and prevented attendance at school and was treated with aripiprazole is presented in this article.

Keywords: childhood masturbation, aripiprazole

Bulletin of Clinical Psychopharmacology 2014;24(1):93-6

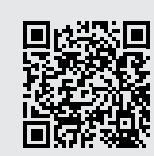

'M.D. Umraniye Training and Research Hospital, Child and Adolescent Psychiatry Clinic, Istanbul - Turkey ${ }^{2}$ M.D. Umraniye Training and Research Hospital, Psychiatry Clinic, Istanbul - Turkey

${ }^{3}$ M.D. Harran University School of Medicine, Department of Child and Adolescent Psychiatry, Sanliurfa - Turkey Address reprint requests to: Dr. Muslum Kul,

Ümraniye Eğitim ve Araștırma Hastanesi,

Çocuk ve Ergen Ruh Sağlığı Kliniği,

İstanbul - Türkiye

E-mail address:

kulmuslum@yahoo.com

Date of submission:

December 17, 2012

Date of acceptance: July 23, 2013

\section{Declaration of interest}

M.K., H.B., H.K.: The authors reported no conflict of interest related to this article.

\section{INTRODUCTION}

Childhood masturbation is characterized by the child's rhythmic stimulation of his/her genital areas generally with an object and accompanying by sweating, flushing and tachypnoea ${ }^{1}$.

In the literature review, no epidemiological studies related to the incidence of childhood masturbation could be found. However, it has been reported that it is frequently seen in routine outpatient practices, especially in preschool children and it leads to varying degrees of concern in families ${ }^{2,3}$.

Traumatic reasons such as the history of a new sibling, staying away from parents or abuse may start masturbation by leading to a decrease in the relationship that the child develops with its environment and turning of the child to his/her own body ${ }^{4}$. Another factor facilitating masturbation is local irritation caused by infection or dermatological diseases of the genital area. Delactation has also been found to be associated with childhood masturbation. In a study by Unal, it has been found that the duration of breast feeding is shorter in the group with childhood masturbation than the siblings of patients and healthy controls ${ }^{5}$.

An early start of masturbation is a factor that increases its continuity; in addition to this, there is spontaneous recovery within two years in most of cases $^{5}$.

Generally, no drug therapy is required in childhood masturbation. Informing the family and dealing with the concerns of the family by 
explaining the course are often the most important steps. Also, the recommendation to improve the quality of the relationship by giving appropriate stimuli to the child and behavioral suggestions to replace the child's existing behavior are usually sufficient. If the frequency of masturbation is still too high and it is performed near strangers and out of the home environment, drug treatment may be necessary. A case of an excessive masturbation that seriously disturbed the functionality of the child, preventing attendance at school and that was treated with aripiprazole is presented in this article.

\section{CASE}

A seven year and two month old female patient was brought by her mother to the outpatient clinic of child psychiatry with a complaint of stretching by flexing the legs and rubbing on objects. According to the information acquired from the mother, this behaviour started first when she was 3 years of age. Previously, she was rubbing on her bed and then falling asleep. Later, she started rubbing on objects during the day, especially the edge of her seat. Without intervention, it continued for 3-5 minutes and she sweated and the frequency of her respiration increased at the same time. She started doing it when she was alone in her room so as not to be exposed to the mother's warnings and punitive attitudes. In the last year, she has been masturbating in crowded environments by stretching her legs to create pubic pressure. The frequency and duration of the complaint have increased in the last 6 months and she has performed it during the day, when she has been out of stimuli in the last 2 months. According to the mother's statement, she has repeated this behavior 15-20 times in a day. The family had to taket the child out of school, because she was conducting this behavior during the lessons. The family was seen by a pediatrician for this complaint. She was directed to a neurologist because the laboratory investigations for probable diagnosis were within normal ranges. Her neurological examination and
EEG were evaluated as normal. An adult psychiatrist was consulted and $1 \mathrm{mg} /$ day risperidone was started because of the excessive masturbation behavior. No prominent decrease in complaints was noted at the follow-up examination after 2 weeks and risperidone was increased to $1.5 \mathrm{mg} /$ day. According to the statements from the family, risperidone was regularly administered for 1 week at a dose of 1.5 mg/day. There was a little decrease in masturbation behavior but the drug was discontinued due to excessive sleepiness and fatigue.

In the mental evaluation, she was a girl who appeared to be her age and dressed appropriately for her socioeconomic status; she had the ability to speak compatible with her age and gave short purposeful responses. There was no effort to talk spontaneously or to maintain the relationship. Reactions from the environment against her behavior and concerns related to the inability to go to school were present in her thought content. Her general knowledge was compatible with her age; she gave the impression of normal intelligence. No symptoms were discovered in support of perception disorder or obsessive compulsive disorder. During observation in the examination room, she was masturbating by stretching her legs to create pubic pressure.

No prominent feature was present in the patient's history. She had reached developmental stages such as walking, talking and toilet training at appropriate times. She had a 2-year old brother. It was understood that there had been problems in the marriage relationship of her mother and father especially for the last 2 years and the mother has left home 2 times for short periods of time. There was no history of a psychiatric disease in the family.

When the history taken from the family as well as clinical observation and medical investigations were evaluated together, the patient was diagnosed as excessive childhood masturbation. The family was informed about the causes, the course and treatment of the situation. Behavioral suggestions were made. Because the patient experienced 
marked sedation with partial benefit from risperidone treatment, $2.5 \mathrm{mg} /$ day aripiprazole oral solution was started after receiving the consent of the family. In the follow-up examination after 10 days, it was stated that there had been a reduction in her complaint; she had been masturbating 5-6 times in a day and therefore the dose was increased to $4 \mathrm{mg}$ because she reported no significant adverse effects. Her complaint decreased significantly with an increase in the dose and there was no complaint after the 3 month follow-up; the medication was reduced by tapering the dose. Her complaint showed no recurrence in follow-up examinations performed after stopping the medication.

\section{DISCUSSION}

Childhood masturbation is one of the reasons for admission to outpatient clinics especially in preschool children. When making a differential diagnosis of masturbation, it is recommended first to investigate the problems that may create local irritation such as urinary tract infections ${ }^{4}$. Bladder stones may also trigger the start of masturbation by a similar mechanism ${ }^{6}$. It is also important to differentiate masturbation from frequently confused neurological situations. In particular, epilepsy and non-epileptic paroxysmal events must be carefully eliminated. In the literature, it is known that many patients have received antiepileptic treatments with neurological diagnoses ${ }^{7-9}$. Autistic disorder and mental retardation are frequently seen conditions in cases with excessive masturbation. It must also be considered in the differential diagnosis whether or not excessive childhood masturbation is a sign of obsessive compulsive disorder. When masturbation is not a tool of satisfaction and becomes joyless and obligatory, compulsive masturbation has been suggested ${ }^{4}$. In the information taken both from her family and herself and in the detailed clinical examination, no signs and symptoms of obsessive compulsive disorder were discovered to explain the excessive masturbation behavior of this case.
Generally, there is no need for drug therapy in childhood masturbation unless it is very frequent and it affects daily functionality of the child. But drug therapy was required in our case due to reasons such as very frequent masturbation, performing in a school environment and preventing school attendance. It has been stated in the literature that good responses to local xylocaine administration were obtained in 3 cases $^{10}$. It has also been reported that escitalopram had the effect of reducing the frequency of masturbation in 3 cases with autistic disorder and excessive masturbation behavior ${ }^{11}$. It has also been observed in a study that mirtazapine had the effect of reducing inappropriate sexual behaviors such as excessive masturbation in children and adolescents with autistic disorder ${ }^{12}$. Studies on the treatment of excessive masturbation are very limited. It is frequently seen especially in autistic disorder and mental retardation. Neither autistic disorder nor mental retardation was present in our case.

Aripiprazole is an atypical antipsychotic with a partial agonistic effect on D2 dopamine receptors and serotonin $1 \mathrm{~A}$ receptors. It has been reported that it showed an antagonistic effect in situations, where the dopamine level is high and shows an agonistic effect when the dopamine level is low. Thanks to this feature, it balances the dopaminergic activity ${ }^{13}$.

There are some publications about the efficiency of aripiprazole in children and adolescents with bipolar disorder, tic disorders, schizophrenia, attention deficit and hyperactivity disorder, pervasive developmental disorder and obsessive compulsive disorder ${ }^{14-19}$.

No controlled, randomized clinical trial on the medical treatment of excessive masturbation was found in the literature review. Considering that the patient had had a partial benefit from risperidone treatment but could not continue due to its excessive sedative effect, aripiprazole, with less sedative effect and a known effect of reducing impulsive behaviors, was preferred. It has been reported in the literature that aripiprazole had the activity to reduce impulsive behaviors, especially 
in autism.

There is a need for randomized, controlled clinical trials about the use of aripiprazole in the treatment of inappropriate sexual behaviors such as excessive masturbation in children and adolescents.

\section{References:}

1. Leung AK, Robson WL. Childhood masturbation. Clin Pediatr (Phila) 1993;32(4):238-41. [CrossRef]

2. Leitenberg H, Detzer MJ, Srebnik D. Gender diferences in masturbation and the relation of masturbation experience in preadolescence and/or early adolescence to sexual behavior and sexual adjustment in young adulthood. Arch Sex Behav 1993;22(2):87-98. [CrossRef]

3. Unal F, Sonuvar B. Childhood Masturbation: A controlled preliminary study.Turkish Journal of Child Adolescent Mental Health 1994;1(2):87-95. (Turkish)

4. Turkbay T. Childhood Masturbation. The Basic Book of Child and Adolescent Psychiatry. Soykan AA, Taner YI (editors). Istanbul 2007.p 747-51. (Turkish)

5. Unal F. The Clinical Outcome of Childhood Masturbation. Turk J Pediatr 2000;42(4):304-7.

6. De Alwis AC, De Silva SM, Rodrigo VS. Bladder calculus presenting as excessive masturbation. Eur J Pediatr. 2008;167(10):1111-7.

7. Shuper A, Mimouni M. Problems of differentiation between epilepsy and non-epileptic paroxysmal events in the first year of life. Arch Dis Child 1995;73(4):342-4. [CrossRef]

8. Fleisher DR, Morrison A. Masturbation mimicking abdominal pain or seizures in young girls. J Pediatr 1990;116(5):810-4. [CrossRef]

9. Mink JW, Neil JJ. Masturbation mimicking paroxysmal dystonia or dyskinesia in a young girl. Mov Disord 1995;10(4):518-20. [CrossRef]

10. Early Childhood Masturbation: A Clinical Study Hiyam Shamoon, MD. Jordan Medical Journal 2005;39(1):23-6.

11. Hergüner S. Excessive masturbation in children and adolescents with autistic disorder: efficacy of escitalopram in three cases. Anatolian Journal of Psychiatry 2009;10 (Suppl1):S101.

12. Coskun M, Karakoc S, Kurcelli F, Mukaddes NM. Effectiveness of Mirtazapine in the Treatment of Inappropriate Sexuel Behaviors in Individuals with Auistic Disorder. J Child Adolesc Psychopharmacol 2009;19(2):203-65. [CrossRef]

13. Kastrup A, Schlotter W, Plewnia C, Bartels M. Treatment of Tics in Tourette Syndrome with Aripiprazole. J Clin Psychopharmacol 2005;25(1):94-6. [CrossRef]

14. Biederman J, Mick E, Spencer T, et al. An open-label trial of aripiprazole monotherapy in children and adolescents with bipolar disorder. CNS Spectr 2007;12:683-9.

15. Findling RL, Short EJ, Leskovec $\mathrm{T}$, et al. Aripiprazole in children with attention deŞcit/hyperactivity disorder. J Child Adolesc Psychopharmacol 2008a;18:347-54. [CrossRef]

16. Findling RL, Robb A, Nyilas $\mathrm{M}$, et al. A multiple-center, randomized, double-blind, placebo-controlled study of oral aripiprazole for treatment of adolescents with schizophrenia. Am J Psychiatry 2008;165(11):1432-41. [CrossRef]

17. Seo WS, Sung HM, Sea HS, et al. Aripiprazole treatment of children and adolescents with Tourette disorder or chronic tic disorder. J Child Adolesc Psychopharmacol 2008;18:197205. [CrossRef]

18. Stigler KA, Diener JT, Kohn AE, et al. Aripiprazole in pervasive developmental disorder not otherwise speciŞed and Asperger's disorder: a 14-week, prospective, open-label study. J Child Adolesc Psychopharmacol 2009;19:265-74. [CrossRef]

19. Storch EA, Lehmkuhl H, Geffken G, et al. Aripiprazole augmentation of incomplete treatment response in an adolescent male with obsessive-compulsive disorder. Depress Anxiety 2008;25(2):172-4. [CrossRef] 